\title{
The Influences of Professional Competence and Teacher Commitment on Learning Quality at Hikmah Sejati Foundation in Banda Aceh
}

\author{
Nuraini Lubis ${ }^{1}$, Murniati ${ }^{2}$, Nasir Usman ${ }^{2}$ \\ ${ }^{1}$ Master of Education Administration, Universitas Syiah Kuala, Indonesia \\ ${ }^{2}$ Universitas Syiah Kuala, Indonesia \\ *Corresponding email: prasart.n@msu.ac.th
}

Received: 01 April 2021

Accepted: 27 July 2021

Published: 30 August 2021

\begin{abstract}
The purpose of this study is to find out whether there are the influences of professional competence and teacher commitment to the learning quality. This research uses the quantitative approach with descriptive method. The population of this research was all teachers at Hikmah Sejati Foundation Banda Aceh. The sample used in this research was 100 people. Moreover, the data analysis used in this research was multiple linear regression This result shows that: (1) partially, the professional competency variable is in good correlation with the percentage of 53 on the learning quality (2) partially, the teacher commitment variable has a fair correlation with the percentage of 33 on the learning quality (3) simultaneously the professional competence and teacher commitment variables have a good correlation with the percentages of $58 \%$ on learning quality. The research result obtained based on the multiple linear regression equation was $\mathrm{Y}=25,655+0,631 \mathrm{X}_{1}+$ $0,43 \mathrm{X}_{2}$ of correlation coefficient is 0.762 . According to statistic test $\mathrm{F}_{\text {score }=67,021}>\mathrm{F}_{\text {table }}=3.09$, with probability level of 0.000 . Therefore, there is a significant correlation between professional competence and teacher commitment to learning quality.
\end{abstract}

Keywords: profesional competence, teacher commitment, learning quality.

Abstrak: Tujuan dari penelitian ini adalah untuk mengetahui apakah ada pengaruh kompetensi profesional dan komitmen guru terhadap kualitas pembelajaran. Penelitian ini menggunakan pendekatan kuantitatif dengan metode deskriptif. Populasi dalam penelitian ini adalah seluruh guru di Yayasan Hikmah Sejati Banda Aceh. Sampel yang digunakan dalam penelitian ini sebanyak 100 orang. Selain itu, analisis data yang digunakan dalam penelitian ini adalah regresi linier berganda. Hasil ini menunjukkan bahwa: (1) secara parsial variabel kompetensi profesional berkorelasi baik dengan persentase 53 terhadap kualitas pembelajaran (2) secara parsial variabel komitmen guru berkorelasi cukup dengan persentase 33 terhadap kualitas pembelajaran (3) secara simultan variabel kompetensi profesional dan komitmen guru memiliki korelasi yang baik dengan persentase 58\% terhadap kualitas pembelajaran. Hasil penelitian yang diperoleh berdasarkan persamaan regresi linier berganda adalah $Y=25,655+0,631 X_{1}+0,43 X_{2}$ dengan koefisien korelasi adalah 0.762. Sesuai uji statistik $F_{\text {score }=67,021}>F_{\text {table }=3.09}$ dengan level probabilitas 0.000 . Oleh karena itu, terdapat hubungan yang signifikan antara kompetensi profesional dengan komitmen guru terhadap kualitas pembelajaran

Kata kunci: kompetensi profesional, komitmen guru, kualitas pembelajaran.

\section{To cite this article:}

Lubis, N., Murniati, \& Usman, N. (2021). The Influences of Professional Competence and Teacher Commitment on Learning Quality at Hikmah Sejati Foundation in Banda Aceh. Jurnal Pendidikan Progresif, 11(2), 419-429. doi: 10.23960/jpp.v11.i2.202122. 


\section{INTRODUCTION}

To realize the constitutional mandate of the 1945 Constitution of the Republic of Indonesia, namely to educate the life of the nation framed in the National Education System in line with Law Number 20 of 2003 concerning Article 3 of the National Education System, as follows:

"National education functions to develop capabilities and form dignified national character and civilization in order to educate the life of the nation, aiming to develop the potential of students to become human beings who believe and fear God Almighty, noble, healthy, knowledgeable, capable, creative, independent, and become a democratic and responsible citizen. Then education development efforts are needed that are in line with the vision of national education".

The vision of national education development in 2025 is to produce Smart and Competitive Indonesians Insan Kamil / Plenary Persons of intelligent Indonesian Persons referred to in the 2025 national education development vision are intelligent, comprehensive people, namely intelligent spiritual, emotionally intelligent, socially intelligent, intellectually intelligent, and smart kinesthetic. So that when this vision of education development is achieved, an institution can be considered quality.

The quality of Learning is a process carried out by individuals to obtain a new behavior change as a whole, as a result of the individual's own experience in interaction with their environment. As mentioned in Law Number 20 of 2003 article 3 concerning the National education system, learning is: "The process of interaction of students with educators and learning resources in a learning environment". So that learning can be said to be of quality if it is successful in changing the attitudes, behaviors, and skills of students associated with educational goals. Quality learning will lead to the ability of teachers in the learning process.
Professional competenceis a job that requires expertise acquired through special education or training. Teacher professional competence is usually related to the teacher's ability to commit to students and their learning process, mastery of teaching material and the way of learning, ability to evaluate learning outcomes, think and do systematic work and learn from existing experiences, and also become active participants in learning communities the environment of his profession. Teachers who already have high professional competence are school assets that must be maintained. This safeguard is expected to come from the teacher's willingness to remain in an educational institution that houses it using commitment. Commitmentis a condition where a person sits with one institution and the purpose of the institution so that the teacher always intends to maintain his membership in the institution. For the continuity and success of education, service improvements and improvements are needed. Therefore, the teacher must have a high commitment so that he can devote his energy to providing the best service according to his role, duties, and functions as a professional teacher.

The Foundation of the Hikmah Sejati is one of the educational institutions in the city of Banda Aceh that began to be glimpsed by the community, becoming the choice of where their children go to school because of a combination of science and technology and applying the general sciences and religious sciences focused on the memorization of the Qur'an each graduating student is targeted to graduate with at least 5 juz Al Quran memorization. This is inseparable from the cooperation or participation of all personnel in the school, one of whom is a teacher. However, as long as the researchers conducted a preliminary study on the Hikmah Sejati Foundation which included the level of Ar Rahmah TKIT in Beurawe, SDIT Nurul Ishlah in Pango 
Deah, and SMPIT Nurul Ishlah in Beurawe it was found that there was a tendency for some teachers to lack professional competence and commitment to doing the task that results in the disruption of learning in school.This phenomenon and description of professional competence and teacher commitment are very interesting to be studied more deeply through research focused on the title "The Influence of Professional Competence and Teacher's Commitment to the Quality of Learning in the Foundation of the Hikmah Sejati of Banda Aceh".

\section{Teacher Professional Competence}

The ability of students to understand the material presented depends on the ability and competence of the teacher in managing to learn (Cottrell, 2019; Brundiers \& Wiek, 2017; Häkkinen et.al., 2017). Teacher competency is a set of knowledge, skills, and behaviors that must be possessed, internalized, mastered, and actualized by the teacher in carrying out his main task (Roostin, 2019; Uerz, Volman, \& Kral, 2018). According to the Indonesian Dictionary, competence means authority (power) to determine (decide) something. Professional teachers are teachers who can manage themselves in carrying out their daily tasks. Thus, the competencies possessed by each teacher will show the quality of the actual teacher (Hoth at.al., 2017; Kaiser et.al., 2017; Korthagen, 2017; Miller, Ramirez, \& Murdock, 2017).

Professional competency is a description of one's qualifications, both qualitative and quantitative in carrying out the profession that they are based on responsibly and professionally. Professional competency as mandated by Permendiknas Number 16 of 2007, has competency indicators which are described as follows:

a. Mastering the material, structure, concepts, and patterns of scientific thinking that support the subjects taught; $b$. Mastering the competency standards and basic competencies of the subjects taught; c. Developing creative learning materials that are taught; d. Develop professionalism on an ongoing basis by taking reflective actions; $\mathrm{e}$. Use information and communication technology to develop themselves.

Professional competency standards can be made tiered according to the ability of the region, school and the resources of the teachers and students they have (Stahmer, Oliver, \& Schetter, 2020; Vernon et.al., 2017). But standards must still refer to national standards. The standard of professional competence of a teacher is very important to realize a qualified teacher, who in the end will realize quality learning as well.

\section{Organizational Commitment}

Organizational commitment is an attitude or behavior of a person to an organization or institution in the form of loyalty and the achievement of the organization's vision, mission, and goals (Batugal, 2019; Ammari et.al., 2017). In line with that Lutheran suggests the following commitments: "1) a strong desire to remain a member of an organization; 2) willingness to work hard on behalf of the organization; 3) certain beliefs and individual acceptance of the values and goals of the organization" (Azizollah, Abolghasem, \& Amin, 2016). In other words, the above understanding is an attitude that reflects member loyalty to the organization and a continuous process where members express their concern for the organization and success and continuous progress. Deeper Steers defines commitment as: "A sense of identification (trust in organizational values), involvement (willingness to try as well as possible for organizational interests), and loyalty (the desire to remain a member) stated by the member towards his organization" (Tao \& Gao, 2017).

Organizational commitment is a strong willingness from members of the organization to remain, work, and feel that they have an 
organization with the following indicators: (1) feeling happy in organization; (2) loyalty to the organization; (3) taking into account the benefits of continuing to work in the organization; (4) calculating losses if leaving the organization; (5) willingness to work; (6) responsibility for advancing the organization (Longman et.al., 2018).

These six elements do not indicate that commitment is a result of something final but is a matter that must be built and is something that grows by the conditions of the organization which are then perceived by its members. Commitment is considered as the loyalty of an individual to the organization (Bricci, Fragata, \& Antunes, 2016). Thus this organizational commitment reflects the level of circumstances in which individuals identify themselves with the organization and are bound to its goals (Pietsch, M., Tulowitzki, \& Koch, 2019; Tsui, 2019). Independently, organizational commitment needs to be built on every individual of the school community including teachers, especially to eliminate the setting of thinking and culture of bureaucratic rigidity, such as having to wait for instructions from superiors by turning them into creative and innovative thoughts without losing the meaning of loyalty.

\section{Learning Quality}

Learning quality is the main thing that must be addressed to improve the quality of education (William, 2017). In this case, the teacher becomes the focal point. The quality of learning is the learning process in schools and their learning outcomes by the needs and expectations of educational stakeholders (Labanauskis, \& Ginevièius, 2017). Quality in the learning process is grouped in input quality, process quality, and quality of learning output (Vicary, Young, \& Hicks, 2017). The quality learning process involves various learning inputs such as students (cognitive, affective, and psychomotor), learning materials, methodologies (varies according to ability teachers), school facilities, administrative support and facilities, and other resources and the creation of a conducive atmosphere.

The preparation of effective learning programs requires careful study so that curriculum planning in each learning can be achieved effectively and efficiently. For the implementation of learning planning to work with well, the teacher must be active in developing his potential through discussions with colleagues, through training or upgrading, as well as activeness in the MGMP forum.

Quality is the totality of the characteristics of a product (goods and services) that supports its ability to satisfy needs specified or specified. To realize quality learning quality, the government issued Government Regulation No. 19 of 2005 concerning National Education Standards (SNP) as a further elaboration of the National Education System Law, which contains process standards. In Chapter I General Conditions for SNP, what is meant by process standards is the national education standard relating to the implementation of learning in educational units to achieve graduate competency standards. Chapter IV Article 19 Paragraph 1 SNP more clearly explains that the learning process in educational units is held interactively, inspiring, fun, challenging, motivating students to actively participate, and providing sufficient space for initiatives, creativity, and abilities according to their talents, interests and physical and psychological development of students.

Indicators of the quality of learning can be understood through the approach of production operations in the industrial field, which is pleasing to input quality, process quality, and output quality". If the quality of input is good, it is processed with a good process, the output is almost certain. Therefore, the success of quality learning is very dependent on the teacher, students, learning facilities, classroom environment, and class culture. All these 
indicators must support each other in a system of quality learning activities and all of these processes require good management.

Management is the process of planning, organizing, leading and controlling elements in the organization (school) to achieve the set goals. So planning is needed learning process. Improving the quality of education through TQM (Total Quality Management) is one of the right ways to improve the quality of education and the quality of organizations (schools). The concept of this approach focused on continuous improvement efforts involving all members of the organization, which includes teachers as one of the important elements in improving the quality of learning.

\section{METHODS}

This research was conducted at the Banda Aceh Hikmah Sejati Foundation, by taking samples from three schools: 20 Ar-Rahmah Banda Aceh TKIT teachers, 60 SDIT teachers Nurul Ishlah Banda Aceh, and 20 SMPIT Nurul Ishlah teachers in BandaAceh. The data collected in this study are data obtained from the teacher's professional competence questionnaire $\left(\mathrm{X}_{1}\right)$, teacher commitment $\left(\mathrm{X}_{2}\right)$ and the quality of learning at the Banda Aceh Hikmah Sejati Foundation (Y). This study uses a quantitative approach. This approach is said to be quantitative because many demand the use of numbers, starting from data collection, interpretation of the data, and appearance of the results. A quantitative approach is an approach based on a positivist philosophy, used to examine certain populations or samples, data collection uses research instruments, data analysis is statistical, with the aim of testing hypotheses. This quantitative approach uses a causal associative method which is a causal relationship, one of the variables (independent) influences the other (dependent) variables.
Associative causal research is research that aims to determine the influence of two or more variables. This study uses three variables, consisting of two independent variables, namely teacher professional competence $\left(\mathrm{X}_{1}\right)$ and teacher commitment $\left(\mathrm{X}_{2}\right)$, and one dependent variable (dependent), namely the quality of learning (Y). To obtain the data needed in this study, researchers conducted data collection by distributing questionnaires to teachers of 100 people where each statement reflects the variables studied, and supports researchers also collected secondary data in the form of structured interviews, structured observations, related documentation, and references.

This study uses validity and reliability. Internal validity, namely calculating the validity based on data and instruments that have been made before. Validity is defined as the proportion relevant to the purpose and test.

Before conducting a regression analysis, normality testing is needed to determine which data cannot be used and is efficient. The normality test is carried out using the Kolmogorov-Smirnov approach, using a 5\% significance level if the Asymp.Sig value. (2-tailed) above a significant value of $5 \%$ means that the residual variable is normally distributed. Then a simple linear regression is performed which aims to study the linear relationship between two variables, the data used are usually interval or ratio scale. Furthermore, data analysis techniques are used, to determine the magnitude of the teacher's professional influence and teacher commitment to improving the quality of education, using a dual relationship model with two independent variables $\mathrm{X}_{1}$ and $\mathrm{X}_{2}$ independent, and one dependent variable $Y$. In accordance with the formula: $Y=a$ $+\mathrm{b} 1 \mathrm{X}_{1}+\mathrm{b} 2 \mathrm{X}_{2}+\mathrm{e}$. Then the hypothesis test is done by using the $t$ test to find out how far the influence of an independent variable partially on the variation of the dependent variable, and the $\mathrm{F}$ 
test to see whether all independent variables included in the model have a joint influence on the dependent variable. And finally the determination coefficient test is used to determine the proportion of total diversity in the dependent variable $(\mathrm{Y})$ which can be explained or explained by the independent variables $(\mathrm{X})$ that exist in the multiple linear regression equation model together.

\section{RESULTS AND DISCUSSION Effect of Teacher Professional Competence on Learning Quality at the Foundation Hikmah Sejati Banda Aceh.}

The research hypothesis proposed is that there is a significant influence between the professional competence of teachers on the quality of learning at the Banda Aceh Hikmah Sejati Foundation. Based on the results of a simple linear regression analysis obtained constant values $a=60.122$ and coefficient $b=0.780$. Thus a simple linear regression equation can be formulated to influence the professional competence of teachers (X1) on the quality of learning at the Hikmah Sejati Foundation Banda Aceh $(Y)$ with the equation $=60.122+0.780$ $\mathrm{X}_{1}$.

Table 4.1 Anova Effect of Teacher Professional Competence on Learning Quality

\begin{tabular}{|c|c|c|c|c|c|c|c|}
\hline & & & $\begin{array}{c}\text { Sum of } \\
\text { Squares }\end{array}$ & Df & $\begin{array}{l}\text { Mean } \\
\text { Square }\end{array}$ & $\mathbf{F}$ & Sig. \\
\hline \multirow{5}{*}{$\begin{array}{c}\text { Mutu } \\
\text { Pembelajaran } \\
\text { (Y) } * \\
\text { Kompetensi } \\
\text { profesional guru } \\
\text { (X1) }\end{array}$} & \multirow{3}{*}{$\begin{array}{l}\text { Between } \\
\text { Groups }\end{array}$} & (Combined) & 21815,68 & 42 & 519,42 & 4,263 &, 000 \\
\hline & & Linearity & 15239,42 & 1 & 15239,42 & 125,07 &, 000 \\
\hline & & $\begin{array}{l}\text { Deviation } \\
\text { from } \\
\text { Linearity }\end{array}$ & 6576,26 & 41 & 160,39 & 1,316 & , 167 \\
\hline & \multicolumn{2}{|c|}{ Within Groups } & 6945,283 & 57 & 121,847 & & \\
\hline & \multicolumn{2}{|c|}{ Total } & $\begin{array}{c}28760,96 \\
0\end{array}$ & 99 & & & \\
\hline
\end{tabular}

Based on the analysis results in the Anova, it is known that for the variable of professional competence, the value of $\mathrm{t}$ test $=5.588$ and $\mathrm{sig}=$ 0.000 . Because the value of $t(0.05 ; 98)=1.987$, it can be said that $t$ test $>t$ table, the value of sig $<0.05$. Thus reject Ho or it can be concluded that the regression equation is significant. Based on the test results, the regression equation expressed with $=60.122+0.780 \mathrm{X}_{1}$ can be used to infer the effect of teacher professional competence on the quality of learning.

The regression above illustrates that the increase in teacher professional competency scores is likely to be followed by an increase in the quality of foundation learning. Quantitatively the professional competence of teachers contributes to the quality of learning by 0.780 in a positive direction with a constant of 60.122 .
This means that the higher the teacher's professional competence, the higher the foundation's learning quality. High professional competence will also encourage teachers to actualize all their abilities and the energy they have to achieve the quality of learning, which in turn increases the quality of the foundation.

The results of the statistical regression analysis questionnaire based on computer output with the help of the SPSS For Windows Release 20 program obtained a coefficient of degree of determination $\left(\mathrm{R}^{2}\right)=0.530$. This means that the teacher's professional competence variable influences the quality of learning by $53 \%$. The influence of professional competence on the quality of learning shows the results of positive and significant regression coefficients. The teacher has a heavy responsibility as an educator with 
regard to how to understand students about knowledge, which finally when students learn well will produce good quality of learning.

The effect of teacher professional competence on the quality of learning by $53 \%$ is due to the fact that there are still some teachers who have not upgraded their competencies as teachers so that they are still not optimal in increasing teacher science. This should be a motivation for teachers to come back to understand what is meant by professional competence. So professional competency is a set of abilities that must be possessed by the teacher so he can carry out teaching assignments.

The competency ability of teachers possessed well will certainly greatly influence the quality of learning, which will ultimately improve the quality of education in schools as in accordance with Harun's opinion (Nurasiah, Murniati, Harun, 2015: 4) which states: "Improving the quality of education through TQM ( Total Quality Management) is one of the right ways to improve the quality of education and quality of the organization (school). "The concept of this approach is focused on efforts to continuously improve by involving all members of the organization.

\section{Influence between Teacher Commitments on Learning Quality at the Foundation Hikmah Sejati Banda Aceh.}

The research hypothesis proposed is that there is a significant influence between the teacher's commitment to the quality of learning at the Banda Aceh Hikmah Sejati Foundation. Based on the results of a simple linear regression analysis, the constant value $\mathrm{a}=50.814$ and the coefficient $b=0.939$ are obtained. Thus a simple linear regression equation can be formulated to influence the commitment of teachers $\left(\mathrm{X}_{2}\right)$ on the quality of learning at the Banda Aceh True Foundation $(\mathrm{Y})$ with the equation $=50.814+$ $0.939 \mathrm{X}_{2}$.

Table 4.2 Anova Influence between Teacher Commitments on Learning Quality

\begin{tabular}{|l|c|c|c|c|c|c|c|}
\hline \multicolumn{2}{|c|}{} & $\begin{array}{c}\text { Sum of } \\
\text { Squares }\end{array}$ & df & $\begin{array}{c}\text { Mean } \\
\text { Square }\end{array}$ & F & Sig. \\
\hline $\begin{array}{l}\text { Mutu Pembelajaran (Y) } \\
*\end{array}$ Komitmen guru (X2) & \multirow{2}{*}{$\begin{array}{c}\text { Between } \\
\text { Groups }\end{array}$} & (Combined) & 15575,452 & 30 & 519,182 & 2,717 &, 000 \\
\cline { 3 - 9 } & Linearity & 9480,802 & 1 & 9480,802 & 49,613 &, 000 \\
\cline { 2 - 8 } & $\begin{array}{c}\text { Deviation from } \\
\text { Linearity }\end{array}$ & 6094,650 & 29 & 210,160 & 1,100 &, 364 \\
\cline { 2 - 8 } & \multicolumn{2}{|c|}{ Within Groups } & 13185,508 & 69 & 191,094 & & \\
\cline { 2 - 8 } & \multicolumn{2}{|c|}{ Total } & 28760,960 & 99 & & & \\
\hline
\end{tabular}

Based on the analysis of the Anova, it is known that the variable of teacher commitment obtained t test $=2.889$ and $\mathrm{sig}=0.005$. Because the value of $t(0.05 ; 98)=1.987$, it can be said that $\mathrm{t}$ test $>\mathrm{t}$ table, the value of $\operatorname{sig}<0.05$. Thus reject Ho or it can be concluded that the regression equation is significant. Based on the results of these tests, the regression equation expressed with $=50.814+0.939 \times 2$ can be used to infer the effect of teacher commitment on the quality of learning. The regression equation above illustrates that the increase in teacher commitment score tends to be followed by an increase in the quality of foundation learning. Quantitatively the teacher's commitment to contribute to the quality of learning amounted to 0.939 in a positive direction with a constant of 50.814. This means that the higher the teacher's commitment, the higher the foundation's learning quality. High commitment will also encourage 
teachers to find new creativity and actualize all their abilities and energy in order to achieve the quality of learning, which in turn increases the quality of the foundation.

The results of the regression statistical analysis based on computer output with the help of the SPSS For Windows Release 20 program obtained a coefficient of degree of determination $\left(\mathrm{R}^{2}\right)=0.330$ This means that the teacher commitment variable influences the quality of learning by $33 \%$. The effect of commitment on the quality of learning shows the results of positive and significant regression coefficients. Teachers have a heavy responsibility as an educator related to how a teacher to continue to be committed to school institutions, because when a teacher has a high commitment it will encourage teachers to concentrate on engaging teaching creativity that makes it easier for students to absorb lessons at school, and in the end it produces a good quality of learning.

professional teacher commitment is an attachment to duties and obligations as a teacher that can give birth to responsive and innovative responsibilities and attitudes towards the development of science and technology, which should be optimized for each individual teacher, but this attitude of responsibility can decrease and increase due to some of them are as stated by Newstrom (Darmawati, Marnis, 2017: 10), namely: "Inhibiting factors and stimulatory factors." If the conditions of the teacher's commitment can be implemented well, it will make it easier for school institutions to have good quality of learning, and when the quality of learning is good, automatically the quality of the Hikmah Banda Aceh Foundation will also be good too.

The Effect of Professional Competence and Teacher's Commitment on the Quality of Hikmah Sejati Learning in Banda Aceh.

The research hypothesis proposed is that there is a significant influence between professional competence and teacher commitment to the quality of learning at the Banda Aceh Hikmah Sejati Foundation. Based on the results of multiple linear regression analysis obtained constant values $\mathrm{a}=25.655$ and coefficient $\mathrm{b} 1=0.631$ and $\mathrm{b} 2=0.431$. Thus, $\mathrm{a}$ double linear regression equation can be formulated to influence professional competence (X1) and teacher commitment (X2) on the quality of learning $(\mathrm{Y})$ at the Banda Aceh True Wisdom Foundation with the same equation: $Y=25.655$ $+0.631 \mathrm{X}_{1}+0.431 \mathrm{X}_{2}$.

Table 4.3 Anova The Effect of Professional Competence and Teacher's Commitment on the Quality of Learning

\begin{tabular}{c|c|c|c|c|c|c|}
\hline \multirow{2}{*}{ Model } & \multicolumn{2}{|c|}{$\begin{array}{c}\text { Unstandardized } \\
\text { Coefficients }\end{array}$} & $\begin{array}{c}\text { Standardized } \\
\text { Coefficients }\end{array}$ & T & F & Sig. \\
\cline { 2 - 4 } & B & Std. Error & Beta & & & \\
\hline $\begin{array}{c}\text { Komptant) } \\
\text { profesional }\end{array}$ & 25,655 & 14,376 & & 1,785 & 67,021 &, 077 \\
\hline Komitmen guru &, 631 &, 083 &, 589 & 7,608 & &, 000 \\
\hline
\end{tabular}


Significance test results are shown in the Anova, the $\mathrm{F}$ test result is 67.021 and $\operatorname{sig}=$ 0.000 . Thus, the value of $\mathrm{F}$ test $>\mathrm{F}$ table $=$ 3.09 and a sig value $<0.05$, means that Ho is rejected or the equation is significant. This positive regression line equation indicates that the better the professional competence and commitment of a teacher, the better the quality of regression can be used to concluded the influence of professional competence and teacher commitment to the quality of learning of the Banda Aceh Hikmah Sejati Foundation.

In addition, based on the values in the Model Summary table, it explains the magnitude of the correlation (R), the coefficient of determination $\left(\mathrm{R}^{2}\right)$, the adjusted coefficient of determination (adjusted $\mathrm{R}^{2}$ ) and the standard error. The correlation coefficient of 0.762 shows a strong influence between the independent variables $\left(\mathrm{X}_{1}\right.$ and $\left.\mathrm{X}_{2}\right)$ with the dependent (Y). The coefficient of determination $\left(\mathrm{R}^{2}\right)$ of 0.580 gives an understanding that $58 \%$ of the quality of learning is influenced by professional competence and teacher commitment.

The results of the statistical regression analysis based on computer output with the help of the SPSS For Windows Release 20 program obtained a coefficient of degree of determination $\left(\mathrm{R}^{2}\right)=0.580$ This means that the variables of professional competence and teacher commitment affect the quality of learning by $58 \%$. The influence of professional competence and teacher commitment to the quality of learning shows the results of a positive and significant regression coefficient. Teachers have a heavy responsibility as an educator related to how a teacher to continue to be committed to school institutions and also try to continue to improve their competencies as a teacher, because when a teacher has high commitment and good competence then it will encourage teachers to give birth works in learning, and in the end produces good quality learning.

The influence of professional competence and teacher commitment to the quality of learning is quite good, due to the quality of learning is a measure that shows how high the quality of teacher and student interaction in the learning process that involves aspects of learning, namely: planning the learning process, implementing the learning process, and evaluating learning outcomes. This is consistent with Hamalik's statement (Mutia, Harun, Usman, 2016: 5) which says that: "The preparation of an effective learning program requires careful study so that curriculum planning in each learning can be achieved effectively and efficiently." going well, teachers must actively develop their potential through discussion with peers, through training or upgrading, as well as activeness in the Subject Teachers' Consultative Forum (MGMP).

This research is supported by Sugiyono (Kesuma, Anggraini, Caisarina. 2017: 4) which states that: "To get the best model, the coefficient of determination criteria, $\mathrm{F}$ or ANOVA test, and t test used to see the significant influence between independent variables and variables The dependent variable must be fulfilled. "Multiple linear regression analysis or $\mathrm{F}$ test is known that the value of $F$ test $>F$ table is $67.021>3.09$ and the significant value $<0.05$, which is 0.000 . This means that there is a significant influence between professional competence and teacher commitment to the quality of learning at the Banda Aceh Hikmah Sejati Foundation. Based on these conclusions it can be said that the tendency to increase the combination of professional competence and teacher commitment will be followed by improvements 
in the quality of learning at the Banda Aceh Hikmah Sejati Foundation.

\section{- CONCLUSION}

Partially the professional competency relationship on the quality of learning. Partially the professional competency variable has a good relationship of $53 \%$ on the quality of learning at the Yayasan Hikmah Sejati Banda Aceh. Partially the teacher commitment relationship on the quality of learning Partially the teacher commitment variable has an adequate relationship of $33 \%$ towards the quality of learning at the Banda Aceh Hikmah Sejati Foundation. Together the variables of professional competence and commitment of teachers have a good relationship of 58\% towards the quality of learning at the Yayasan Hikmah Sejati Banda Aceh.

\section{REFERENCES}

Ammari, G., Alkurdi, B., Alshurideh, A., \& Alrowwad, A. (2017). Investigating the impact of communication satisfaction on organizational commitment: a practical approach to increase employees' loyalty. International Journal of Marketing Studies, 9(2), 113-133.

Azizollah, A., Abolghasem, F., \& Amin, D. M. (2016). The relationship between organizational culture and organizational commitment in Zahedan University of Medical Sciences. Global journal of health science, 8(7), 195.

Batugal, M. L. C. (2019). Organizational Culture, Commitment and Job Satisfaction of Faculty in PrivateSectarian Higher Education Institutions (HEIs). World Journal of Education, 9(2), 123-135.

Bricci, L., Fragata, A., \& Antunes, J. (2016). The effects of trust, commitment and satisfaction on customer loyalty in the distribution sector. Journal of Economics, Business and Management, 4(2), 173177.

Brundiers, K., \& Wiek, A. (2017). Beyond interpersonal competence: Teaching and learning professional skills in sustainability. Education Sciences, 7(1), 39.

Cottrell, S. (2019). The study skills handbook. Macmillan International Higher Education.

Häkkinen, P., Järvelä, S., Mäkitalo-Siegl, K., Ahonen, A., Näykki, P., \& Valtonen, T. (2017). Preparing teacher-students for twenty-first-century learning practices (PREP 21): a framework for enhancing collaborative problem-solving and strategic learning skills. Teachers and Teaching, 23(1), 25-41.

Hoth, J., Kaiser, G., Busse, A., Doehrmann, M., Koenig, J., \& Blömeke, S. (2017). Professional competences of teachers for fostering creativity and supporting highachieving students. ZDM, 49(1), 107120.

Kaiser, G., Blömeke, S., Koenig, J., Busse, A., Doehrmann, M., \& Hoth, J. (2017). Professional competencies of (prospective) mathematics teachersCognitive versus situated approaches. Educational Studies in Mathematics, 94(2), 161-182.

Korthagen, F. (2017). Inconvenient truths about teacher learning: Towards professional development 3.0. Teachers and teaching, 23(4), 387-405.

Labanauskis, R., \& Ginevičius, R. (2017). Role of stakeholders leading to development of higher education services. Engineering Management in Production and Services, 9(3), 63-75. 
Longman, K., Daniels, J., Bray, D. L., \& Liddell, W. (2018). How organizational culture shapes women's leadership experiences. Administrative Sciences, $8(2), 8$.

Miller, A. D., Ramirez, E. M., \& Murdock, T. B. (2017). The influence of teachers' selfefficacy on perceptions: Perceived teacher competence and respect and student effort and achievement. Teaching and Teacher Education, 64, 260-269.

Pietsch, M., Tulowitzki, P., \& Koch, T. (2019). On the differential and shared effects of leadership for learning on teachers' organizational commitment and job satisfaction: A multilevel perspective. Educational Administration Quarterly, 55(5), 705-741.

Roostin, E. (2019). The Importance of Government Policy Regarding Teacher Recruitment to Increase Motivation for Professionalism, Competence and Effectiveness of Certification Programs. International Journal of Advances in Social and Economics, 1(2), 67-72.

Stahmer, A., Oliver, K., \& Schetter, P. (2020). Improving Education for California Students via Professional Development.

Tao, J., \& Gao, X. (2017). Teacher agency and identity commitment in curricular reform. Teaching and Teacher Education, 63, 346-355.

Tsui, K. T., Lee, J. C. K., Zhang, Z., \& Wong, P. H. (2019). The Relationship Between Teacher Perceived Spiritual Leadership and Organizational Commitment: A Multlevel Analysis in The Hongkong Context. Asian Journal of Social Sciences \& Humanities Vol, 8, 3.

Uerz, D., Volman, M., \& Kral, M. (2018). Teacher educators' competences in fostering student teachers' proficiency in teaching and learning with technology: An overview of relevant research literature. Teaching and Teacher Education, 70, 12-23.

Vernon-Feagans, L., Bratsch-Hines, M., Varghese, C., Cutrer, E. A., \& Garwood, J. D. (2018). Improving struggling readers' early literacy skills through a Tier 2 professional development program for rural classroom teachers: The targeted reading intervention. The Elementary School Journal, 118(4), 525548.

Vicary, S., Young, A., \& Hicks, S. (2017). A reflective journal as learning process and contribution to quality and validity in interpretative phenomenological analysis. Qualitative Social Work, 16(4), 550-565.

Wiliam, D. (2017). Assessment and learning: some reflections. Assessment in Education: Principles, Policy \& Practice, 24(3), 394403. 